\title{
Productivity and Real Exchange Rate: Investigating the Balassa-Samuelson Effect and misalignment in Five African Countries
}

\author{
Joel Hinaunye Eita* ${ }^{*}$, Zitsile Zamantungwa Khumalo**iD, Ireen Choga***iD
}

\begin{abstract}
The study aims to investigate the validity of the Balassa-Samuelson Effect in a sample of five African countries, the Democratic Republic of Congo, Mauritius, Morocco, South Africa and Tunisia for the period 1991 to 2016. The study first estimates the equilibrium real exchange rate with variables real exchange rate, productivity, terms of trade and net foreign assets. Secondly, real exchange rate misalignment is derived and lastly, the effects of real exchange rate misalignment on economic performance are tested. For the methodology, the Fully Modified Ordinary Least Squares (FMOLS) and pool mean group econometric (PMG) techniques were utilised. The outcomes of the study indicate a valid Balassa-Samuelson effect in all five African countries and a negative effect of real exchange rate misalignment on economic performance. The study contributes to scientific progress by introducing an appropriate measure of total factor productivity in testing for the validity of the Balassa-Samuelson hypothesis.
\end{abstract}

Keywords: Balassa-Samuelson effect; real exchange rate; real exchange rate misalignment.

JEL classification: C32; C51; F14; F32.

\section{INTRODUCTION}

The Balassa-Samuelson hypothesis examines the relationship between productivity growth and real exchange rate appreciation. Countries with higher productivity levels than their trading partners tend to have better productivity differentials in traded goods sectors than non-traded goods sectors. With higher productivity in traded goods, the movement of labour from the non-traded goods sector is allowed thereby increasing costs in the non-traded goods sector. This results in higher relative prices of non-traded goods to sustain profitability in the sector (Montiel, 2007). Conversion to the same currency means differences in price levels

\footnotetext{
"School of Economics, University of Johannesburg, Johannesburg, South Africa; e-mail: hinaeita@yahoo.co.uk or jeita@uj.ac.za (corresponding author).

"School of Economics, University of Johannesburg, Johannesburg, South Africa; e-mail: zitsilek@gmail.com.

${ }^{* * *}$ Department of Economics, North-West University, Mmabatho, South Africa; e-mail: ireen.choga@nwu.ac.za.
} 
between countries due to differences in the productivity differential between the non-tradable and the tradable sector. The hypothesis also adopts the law of one price for tradable goods (Gubler and Sax, 2019).

The Balassa-Samuelson hypothesis is normally a growing economy phenomenon as fastgrowing countries experience real exchange rate appreciations as opposed to slow-growing countries. Ito and Krueger (2007) state that the hypothesis may be invalid in countries emerging from being primary goods exporters or planned economies, regardless of fast-paced growth. This has resulted in African economies, most of which are synonymous with slowgrowth, to prioritise industrialisation for development planning and management. Historically, African countries like South Africa and Mauritius have experienced many disadvantages such as de-industrialisation and low manufacturing value added levels compared to other global regions (Moyo, 2016).

The hypothesis further implies a correlation between relative economic development and the real exchange rate by connecting improvements in the tradable sector productivity to economic growth. Given the constant restructuring of African economies in pursuit of development and catching-up with the rest of the world, it is imperative to test for the validity of the hypothesis. This will gauge the developmental stance of some African economies in terms of present exchange rate movements which are crucial for trade and the overall development of an economy. In this way, the developmental progress of Africa over the years is tracked and prospective development for the future is forecasted. Thus, the purpose of this article is to investigate the validity of the Balassa-Samuelson hypothesis in selected African countries.

There are several studies in literature that have investigated the Balassa-Samuelson hypothesis for both advanced and emerging economies (Drine and Rault, 2004; Gubler and Sax, 2019; Hussain and Haque, 2020). It is important to highlight that even if the real exchange rate equilibrium is estimated using the Balassa-Samuelson effect, it is likely that there will be resulting misalignment. Misalignment of real exchange can have a negative effect on economic performance. Despite the fact that many countries experience real exchange rate misalignment, most empirical studies do not test the effect of misalignment on economic performance. The few studies that investigate the impact of misalignment on economic performance (such as Sallenave, 2010; Kakkar and Yan, 2012; Vieira and Macdonald, 2012; Udah and Ite, 2016) are based on inappropriate measure of technology (such as real GDP, GDP per capita or relative GDP). This is despite the fact that technology or productivity is an important variable in testing the Balassa-Samuelson effect. For instance, GDP per capita does not properly explain productivity differences, as an increase (decrease) in relative efficiency of the distribution sector in regard to foreign countries causes depreciation (appreciation) of the exchange rate. These previous studies also did not test appropriately the effect of misalignment on economic performance and most used one measure of economic performance.

Contrary to previous studies, this study uses an appropriate measure of technology or productivity. It computes total factor productivity using the Cobb-Douglas production function. Employing a suitable measure of productivity is important to produce accurate results that may be used appropriately, for instance, in policy advising for African countries seeking economic prosperity. Further, real exchange rate misalignment is derived and its impact on economic performance is tested using two measures of economic performance for robust results. It is in this regard that this study makes a contribution to literature. The selected countries for this estimation are the Democratic Republic of Congo, Mauritius, Morocco, South Africa and Tunisia and their selection was on the premise of data availability. 
The rest of the study is organised as follows. Section 2 presents an overview of selected countries. Section 3 presents the literature review. Section 4 provides a description of data and descriptive statistics. Section 5 presents the empirical model for the Balassa-Samuelson effect. Section 6 presents the estimation technique. Section 7 estimated empirical models and the methodology. Section 7 presents the empirical results, while the conclusion is presented in Section 8.

\section{AN OVERVIEW OF ECONOMIC PERFORMANCE OF SELECTED AFRICAN COUNTRIES}

This section presents the economic positions of the countries selected in this study for the period 1980 - 2020. The selected countries are the Democratic Republic of Congo, Mauritius, Morocco, South Africa and Tunisia. Like all developing countries, these are on an ongoing discourse and effort of attaining various developmental goals (for example, poverty eradication) to achieve economic prosperity and stability.

The annual growth rate of the Democratic Republic of Congo (DRC) for periods 1990 to 1995 was -8.42 percent (Britannica, 2021a). For 2021, growth projections suggest a downturn of $3.4 \%$ due to reduced mining production. The current account deficit is projected to deteriorate to $4.3 \%$ of GDP in 2021 (African Economic Outlook, 2020a). The exchange rate in the DRC is cited by Alex and Simon (2018) as a key variable that determine macroeconomic stability. It is there important to investigate the equilibrium real exchange rate, resulting real exchange rate misalignment and economic performance.

In Mauritius, the 1990s and 2000s saw an increase in the gross domestic product as its growth exceeded the growth of the population (Britannica, 2021b). Currently, projections suggest real GDP growth to be $4.0 \%$ in 2021, attributed to increased tourism, steady investment growth, and external demand from regional and global growth (African Economic Outlook, 2020b). In Morocco, the government moved towards privatization and economic reforms in the mid-1980s and started a loan fund to stimulate growth in 1999 (Britannica, 2021c). In 2019, real GDP growth slowed to $2.9 \%$ in and the deceleration was sustained. Unchanging GDP composition reflects the low productivity of agriculture and industry, however, the medium-term outlook remains positive with real GDP growth expected to reach $3.9 \%$ in 2021 (African Economic Outlook, 2020c).

While, the South African economy is based on private enterprise with state participation at many levels. In the 1990s, the government partially privatized airlines and telecommunications, and official economic policy continued to include partially or completely privatizing many public enterprises (Britannica, 2021d). The South African economy experienced a setback in 2020 due to the COVID-19 outbreak with a negative growth balance of $8.0 \%$. However, the international monetary fund (IMF) projected growth of the GDP to be at 3\% in 2021 and to stabilise in 2022 at $1.5 \%$. (Export Enterprises SA, 2021).

Tunisia once held the position of second strongest real GDP per capita growth in the Middle East and North Africa (MENA) region. However, in the late 1990s, the economy did not progress, and economic performance remained insufficient (Jobs and Tunisians, 2014). In 2019 , real GDP growth decreased to $1.5 \%$ with growth in the agriculture and fishing sectors falling to $1.7 \%$ in 2019 from $9.8 \%$ in 2018 . Real GDP growth is projected to improve to $2.6 \%$ in 2021, attributed to the supply side by agriculture, phosphates, and tourism sectors (African Economic Outlook, 2020d). 


\section{LITERATURE REVIEW}

The kernel of the Balassa-Samuelson effect is the effect of productivity on the real exchange rate. Balassa (1964) and Samuelson (1964) pioneered the hypothesis through different studies presenting a description of real exchange rate differentials across countries with productivity differences. However, other studies consider the hypothesis to have been founded in 1933 by Harrod and refer to the hypothesis as the "Harrod-Balassa-Samuelson Hypothesis" (for instance, Rogoff, 1992; Obstfeld et al., 1996; Tica and Družić, 2006).

Since then, several studies have used various methodologies and country-specific Balassa-Samuelson coefficients to test the validity of the hypothesis in different countries. The first author to formulate a complete "Harrod-Balassa-Samuelson model based on a general equilibrium framework, specifically, the standard production function was Rogoff (1992). Other notable authors include Asea and Mendoza (1994) who were first to model utility functions and the demand side of the economy. De Gregorio et al. (1994) also included the demand side of the economy with slightly different findings to Asea and Mendoza (1994) with regards to the ability of productivity differential sin explaining changes across countries in the real exchange rate.

Theoretically, productivity is expected to cause real exchange rate appreciation. It is expected that even if the equilibrium real exchange rate is computed using the BalassaSamuelson effect, there will be resulting real exchange rate misalignment. Real exchange rate misalignment means that the real exchange rate is out of equilibrium. This suggest that there is either overvaluation of undervaluation of the real exchange rate. This study first reviews previous research, which focused on just testing the Balassa-Samuelson effect. Secondly, it will then review studies that tested the effect of misalignment of economic performance.

There is extensive literature on the Balassa-Samuelson effect in both developed and developing economies. Recent studies like Gubler and Sax (2019) investigated the robustness of the Balassa-Samuelson hypothesis for panel of OECD countries for the period of 1970 to 2008 using the dynamic ordinary least squares (DOLS) model specifications and betweendimension group-mean panel Fully Modified Ordinary Least Squares (FMOLS) estimator from Pedroni (2001). The study did not find evidence in support of the Balassa-Samuelson hypothesis. Hussain and Haque (2020) employed panel data for 182 countries for the period 1950 to 2017 to investigate the Balassa and Samuelson hypothesis. The investigation was based on the relationship between real exchange rate and total factor productivity relative to the United States. Findings of the study showed validity of the hypothesis through an inverse relationship; an increase in productivity led to an increased real exchange rate. Additional tests further confirmed a long-run relationship between real exchange rate and relative factor productivity.

Iyke and Odhiambo (2017) tested for the hypothesis for eight African countries. The study covered the period 1960 to 2009 and used generalised methods of moments. The results provided strong evidence in favour of the Balassa-Samuelson effect. That means an improvement in productivity causes real exchange rate appreciation. Berka et al. (2018) modified the Balassa-Samuelson model to include sectoral productivity shocks and a labor market wedge in their investigation of the relationship between real exchange rates and sectoral TFP for Eurozone countries. Findings of the study contrast showed a valid BalassaSamuelson hypothesis in these countries.

Bordo et al. (2017) surveyed the long-run effect of productivity on the real exchange rate in 14 countries for the period 1880-1997. Findings of the study showed indistinct results 
regarding the hypothesis, as productivity as a determinant of the real exchange rate was evident, while the size and the sign of the productivity effect, appeared to be sensitive to the data sets and varied from one study to study.

Ishaq (2016) estimated equilibrium real exchange rates using the Balassa-Samuelson hypothesis for developing economies of East and South Asia (ASEAN and SAARC). Three inter-related dimensions of productivity-real exchange rate linkage were employed with findings inconsistent with the hypothesis. They suggested an insignificant effect on the long-run real exchange rates for the ASEAN and SAARC countries by inter-country divergent sectoral productivity patterns. The biased relative productivity of tradables at home influencing the overall price level of the country through nontraded sector prices and contribution to long-run movements of real exchange rates postulation of the hypothesis was invalid.

Earlier studies like Tintin (2009) investigated the Balassa-Samuelson hypothesis in ten OECD countries for the period 1975 and 2007 with findings suggesting that the BalassaSamuelson effect holds for these ten OECD economies. Sonora and Tica (2014) examined the Balassa-Samuelson effect in eleven Central and Eastern European transition countries with the results that the hypothesis holds under the assumption that the law of one price for tradables does not hold. Kakkar and Yan (2012) went a little bit further by deriving real exchange rate misalignment. Tipoy et al. (2018), Elbadawi et al. (2012), Sallenave (2010) and Vieira and Macdonald (2012) went on to test the relationship between real exchange rate misalignment and economic performance.

These studies suffer from shortcomings in the sense that real change rate and resulting misalignment are derived based on some inappropriately computed determinants such as productivity. They used relative GDP as a measure of productivity and this not appropriate. These previous studies also did not compute the equilibrium real exchange rate properly. Most of the previous studies also used just one measure of economic performance.

To fill the gap of previous studies, this study estimates the Balassa-Samuelson effect using an appropriate measure of productivity. Productivity in this study is computed using the Cobb-Douglas production function. This study also computes the equilibrium real exchange rate properly. To create an equilibrium real exchange rate, the permanent values of explanatory variables are computed using the Hodrick-Prescott filter (HP). The estimated coefficients are then imposed on the permanent values of the explanatory variables in order to appropriately derive the equilibrium real exchange rate and the resulting misalignment. Finally, this study uses more than one measure of economic performance to determine the impact of real exchange rate misalignment.

\section{DATA AND DESCRIPTIVE STATISTICS}

To investigate the Balassa-Samuelson hypothesis and resulting misalignment and economic performance, the study uses annual data for the period 1991 to 2016. Five countries are included in the analysis. These are Democratic Republic of Congo, Mauritius, Morocco, South Africa and Tunisia. The data are obtained from Quantec database. The sample period and the countries under investigation are selected on the premise of data availability.

The variables are real exchange rate are (RER) computed as the real effective exchange rate sourced directly from the database; total factor productivity (PR) computed using the standard Cobb Douglas production function as; terms of trade (TT) sourced from the Quantec database; net foreign assets (NFA) sourced from the Quantec database; real exchange rate misalignment 
(MIS) computed as the difference between actual and equilibrium real exchange rate; the gross domestic product (Y), public investment (PIN), population (POP) sourced from the database; unit labour costs (ULC) computed as remuneration of employees divided by total GDP; foreign direct investment (FDI), export of goods and services (X) and inflation (INF), all sourced from the Quantec database. All variables were transformed into logarithms which rescales data for a constant variance, a more positively skewed distribution closer to normal distribution and the turning of a non-linear multiplicative relationship between variables into a linear and additive one (Brooks, 2008). Table no. 1 presents descriptive statistics of the variables. Table no. 1 shows that RER ranges from 3.89 to 5.59. RER has the average of 4.629. MIS ranges from -0.683 to 1.078. The variable ULC ranges from -256.042 to 497.590 . The variable $Y$ has the highest average of 28.438 followed by FDI (26.138). ULC has the highest variation with a standard deviation of 47.681. The variable with the second highest variation is NFA with a standard deviation of 19.708. The lowest variation is recorded for MIS, with a standard deviation of 0.249. RER has the second lowest variation with a standard deviation of 0.255 .

Table no. 1 - Descriptive statistics

\begin{tabular}{llccc}
\hline Variable & Mean & Minimum & Maximum & Standard Deviation \\
\hline RER & 4.629868 & 3.893111 & 5.597474 & 0.255322 \\
\hline PR & -13.72562 & -16.02898 & -10.26628 & 1.509728 \\
\hline TT & 4.646615 & 3.063238 & 5.597230 & 0.420078 \\
\hline NFA & 16.96484 & -26.58181 & 30.37841 & 19.70892 \\
\hline MIS & $-2.33 \mathrm{E}-13$ & -0.683073 & 1.078035 & 0.249470 \\
\hline Y & 28.43887 & 22.90871 & 31.87638 & 2.173030 \\
\hline PIN & 3.188086 & 1.367112 & 4.745819 & 0.464594 \\
\hline POP & 1.330599 & -2.77856 & 5.017101 & 1.216661 \\
\hline ULC & 9.413287 & -256.0422 & 497.5908 & 47.68123 \\
\hline FDI & 26.13885 & 19.93044 & 29.79595 & 2.091956 \\
\hline X & 2.133226 & -0.083382 & 3.787751 & 0.978995 \\
\hline INF & 4.371597 & 1.99606 & 5.500491 & 0.630792 \\
\hline \multicolumn{5}{c}{ Source: Computed by the authors }
\end{tabular}

\section{EMPIRICAL MODEL FOR THE BALASSA-SAMUELSON EFFECT}

The empirical model for Balassa-Samuelson effect is discussed first before real exchange rate misalignment. Following an extensive review of the empirical literature, the empirical model for testing the validity of the Balassa-Samuelson effect is specified as follows:

$$
R E R_{i t}=\beta_{0}+\beta_{1} P R_{i t}+\beta_{2} T T_{i t}+\beta_{3} N F A_{i t}+\varepsilon_{i t}
$$

where $R E R_{i t}, P R_{i t}, T T_{i t}, N F_{i t}, \varepsilon_{i t}$ are real exchange rate, total factor productivity, terms of trade, net foreign assets and residuals.

An increase in real exchange rate is an appreciation and a decrease is depreciation. The Balassa-Samuelson effect postulates that an increase in total factor productivity will cause an increase in real exchange rate appreciation.

The impact of terms of trade is ambiguous due to income and substitution effects. If the substitution effect dominates income effect, an increase in terms of trade will cause real exchange rate depreciation. However, if income effect dominates the substitution effect, an increase in terms of trade will cause real exchange rate appreciation. An increase in capital 
inflows allows an expansion of absorption and subsequently, an appreciation of the real exchange rate. Net foreign assets are cumulative current account of net capital transfers adjusted for the effects of capital gains and losses on inward and outward FDI as well as on portfolio equity holdings (Lane and Milesi-Ferretti, 2000). Net foreign asset is expected to have a positive relationship with the real exchange rate (Bleaney and Tian, 2014).

\subsection{Real exchange rate misalignment}

The next step after estimating the equilibrium real exchange rate is to derive the real exchange rate misalignment. The shift of the real exchange rate from its desired equilibrium is called real exchange rate misalignment. It is computed by subtracting the equilibrium real exchange rate from the actual exchange rate as follows:

$$
M I S_{i t}=R E R_{i t}-E R E R_{i t}
$$

where MIS is real exchange rate misalignment, RER is the actual real exchange rate, and $E R E R$ is the equilibrium real exchange rate. A positive value signals an overvalued real exchange rate while a negative value signals an undervalued real exchange rate. Both incidences affect the economic performance of a country.

\subsection{Real exchange rate and economic performance}

The final step involves testing the effect of real exchange rate misalignment on measures of economic performance. This study investigates the effect of real exchange rate misalignment on measures of economic performance.

Two models are estimated in order to investigate the effect of real exchange rate misalignment on measures of economic performance. The first model uses GDP as an indicator of economic performance. The second model uses unit labour costs as a measure of economic performance. Unit labour costs is computed as remuneration of employees divided by total output of the economy as in Eita and Jordaan (2013). This study follows the same procedure for each country. Eita and Jordaan (2013) mention that real exchange rate misalignment may upsurge unit labour costs and weaken the competitiveness of a country. Lipská et al. (2005) recognise unit labour cost (ULC) indicator as an important economic indicator. The first model follows the form of Barro's simple model of endogenous growth of Barro (1990). It is expressed as follows:

$$
Y=A K^{\alpha} G_{Y}^{\beta}
$$

where Y, A, K, G are real output, productivity, capital, and public investment. Equation (3) is linearized and other variables are added as follows:

$$
Y_{i t}=\alpha_{0}+\alpha_{1} P R_{i t}+\alpha_{2} P I N V_{i t}+\alpha_{3} P O P_{i t}+\alpha_{4} M I S_{i t}+\varepsilon_{i t}
$$

where $P R$ is total factor productivity, $P I N V$ is public investment proxied by government spending, $P O P$ represents population growth and $M I S$ is real exchange rate misalignment. The variable of interest in equation (4), real exchange rate misalignment is expected to impact negatively on economic growth. However, there are also some few studies which concluded that it is possible for real exchange rate misalignment to have a positive impact or no effect at all on economic growth. Greater productivity enables firms to produce more output with the 
same input resources thus higher revenues and ultimately a higher gross domestic product. Public investment may affect growth positively or negatively. Primarily, public investment causes increased production, which increases output and the employment level (Rabnawaz and Jafar, 2015). Population growth increases causes a decline in growth. The second model uses another measure of economic performance, and is expressed as follows:

$$
U L C_{i t}=\alpha_{0}+\alpha_{1} I N F_{i t}+\alpha_{2} F D I_{i t}+\alpha_{3} X_{i t}+\alpha_{4} M I S_{i t}+\varepsilon_{i t}
$$

where $U L C$ is the unit labour cost, INF denotes inflation, FDI denotes foreign direct investment, $\mathrm{X}$ is export of goods and services, and MIS is as previously defined. Higher inflation raises unit labour costs. There is a positive relationship between inflation and unit labour costs. A negative relationship exists between foreign direct investment and unit labour costs. Falling unit labour costs encourages foreign direct investment. Exports of goods and services are expected to impact negatively on unit labour costs. The variable of interest in equation (5), real exchange rate misalignment is expected worsen unit labour costs. An increase in real exchange rate misalignment causes unit labour cost to increase.

\section{ESTIMATION TECHNIQUE}

This study uses two estimation techniques. The first is fully modified ordinary least squares (FMOLS). This technique was created to directly estimate cointegrating relationships by altering the traditional ordinary least squares. It corrects endogeneity and serial correlation. FMOLS performs better than other methods in estimating cointegrating relations as cited by Cappuccio and Lubian (1992) and Hargreaves (1993) (Phillips, 1995). Based on the premise of the FMOLS method producing reliable estimates and robustness checks of the results, particularly for small sample sizes, it was used to estimate the real exchange rate equation (Balassa-Samuelson effect).

After estimation of the Balassa-Samuelson effect as specified in equation (1), the equilibrium real exchange rate is computed. To compute the equilibrium real exchange rate, the permanent values of the explanatory variables in equation (1) are derived using the Hodrick-Presscott filter. Then the estimated coefficients are imposed on the permanent values of the explanatory variables in order to derive the equilibrium real exchange rate. The real exchange rate misalignment is then computed as the difference between actual and equilibrium real exchange rate.

The second estimation technique is pooled mean group estimator (PMG). The PMG is consistent and efficient in the estimation of parameters' averages and long-run estimators for large sample sizes (Pesaran and Smith, 1995). Parameters are independent across groups and potential homogeneity between groups is not considered. Short-run dynamic specifications differ from country to country and long-run coefficients are controlled to be similar. The PMG pertains maximum likelihood estimation of an ARDL model which can be written as an error correction model (ECM). It is a panel version of the ARDL (Saxegaard et al., 2007). The PMG is used test the impact of real exchange rate misalignment on economic performance.

Before the estimation of Balassa-Samuelson effect and the impact of real exchange rate misalignment on economic performance, it is important to test the univariate characteristics of the data. This involves panel unit root test. This study applies Levin, Lin and Chu (LLC); and the Im, Pesaran, Shin (IPS) test statistics for this purpose. The LLC covers the shortfall of individual unit root tests. Individual unit root tests lack sufficient power against alternative hypotheses with rapid constant deviations from equilibrium (Baltagi, 2008). The Im-Pesaran-Shin (IPS) test is more flexible than the Levin-Lin-Chu test because it permits heterogeneous coefficients. 
The study then applies Kao cointegration test statistics in order to investigate the existence of the long-run economic equilibrium relationship between the variables (Chaiboonsri, 2010). The Kao test was chosen because it accounts for spurious regression of panel data by employing two types of panel cointegration tests, the Dickey-Fuller (DF) and augmented Dickey-Fuller (ADF) tests. The existence of a cointegration amongst variables is followed by an estimation of the real exchange rate model. Based on its properties of providing optimal estimates of cointegrating regressions and accounting for serial correlation and endogeneity of regressors as proposed by Hansen and Phillips (1989), the FMOLS is applied. The same applies to the PMG.

\section{ESTIMATION RESULTS}

\subsection{Estimation of real exchange rate (Balassa-Samuelson effect)}

\subsubsection{Unit Root (Stationarity) Tests}

It is important to establish univariate characteristics of the variables before estimation of the empirical model. The variables are subjected to the LLC and the IPS stationarity tests at levels and first difference. At levels, only $T T$ is stationary at 10 per cent level of significance. The variables $R E R, P R, N F A$ become stationary at first difference. This means $T T$ is integrated of order zero or $\mathrm{I}(0)$, while $R E R, P R$ and $N F A$ are integrated of order one or I(1). Since most variables are $\mathrm{I}(1)$, the next step is to test if the variables are cointegrated. Table no. 2 presents the stationarity results:

Table no. 2 - Stationarity Results

\begin{tabular}{lcccc}
\hline Variable & \multicolumn{2}{c}{ LLC Test } & \multicolumn{2}{c}{ IPS Test } \\
\hline & \multicolumn{2}{c}{ Levels } & \multicolumn{2}{c}{ Levels } \\
\hline CRER & -0.07054 & -1.14415 & 0.79557 & -1.07910 \\
& $(0.4719)$ & $(0.1263)$ & $(0.7869)$ & $(0.1403)$ \\
\hline LPR & -1.15240 & -0.92410 & 1.50259 & -0.05751 \\
& $(0.1246)$ & $(0.1777)$ & $(0.9335)$ & $(0.4771)$ \\
\hline LTT & -0.68398 & -0.32210 & 0.37277 & -1.37595 \\
& $(0.2470)$ & $(0.3737)$ & $(0.6453)$ & $(0.0844)^{*}$ \\
\hline LNFA & 0.01093 & 0.79499 & 1.92327 & 3.01484 \\
& $(0.5044)$ & $(0.7867)$ & $(0.9728)$ & $(0.9987)$ \\
\hline Variable & \multicolumn{2}{c}{ First Difference } & & First Difference \\
\hline & Constant & Constant and Trend & Constant & Constant and Trend \\
\hline LRER & -8.16733 & -6.60331 & -7.04103 & -5.65658 \\
& $(0.0000)^{*}$ & $(0.0000)^{*}$ & $(0.0000)^{*}$ & $(0.0000)^{*}$ \\
\hline LPR & -9.43767 & -7.70112 & -8.46954 & -6.76304 \\
& $(0.0000)^{*}$ & $(0.0000)^{*}$ & $(0.0000)^{*}$ & $(0.0000)^{*}$ \\
\hline LTT & -8.27779 & -7.25819 & -8.37758 & -6.92036 \\
& $(0.0000)^{*}$ & $(0.0000)^{*}$ & $(0.0000)^{*}$ & $(0.0000)^{*}$ \\
\hline LNFA & -5.00458 & -4.11256 & -3.19374 & -2.31718 \\
& $(0.0000)^{*}$ & $(0.0000)^{*}$ & $(0.0007)^{*}$ & $(0.0102)^{*}$ \\
\hline
\end{tabular}

Notes: probability values are in parentheses ()$; *$ indicates rejection of the null hypothesis of unit root at $1 \%, 5 \%$ and $10 \%$ levels of significance

Source: computed by the authors 


\subsubsection{Real exchange rate cointegration test results}

Table no. 3 presents the Kao panel cointegration test results. The decision rule of this test is rejecting the null hypothesis of no cointegration when the probability value is less than 5 per cent. The results in this study are consistent with this rule therefore there is cointegration amongst the variables. The presence of cointegration suggest that it is now appropriate to estimate the long-run results using FMOLS.

Table no. 3 - Kao Cointegration Test Results

\begin{tabular}{ccc}
\hline Cointegration test & t-statistic & Probability \\
\hline Kao Test & -4.051 & $0.000^{*}$ \\
\hline Notes: The ADF is the residual-based ADF statistic. The null hypothesis is no cointegration. \\
$*$ Indicates rejection of the null of no cointegration at the 5 per cent significance level. \\
Source: author's own computation
\end{tabular}

\subsubsection{Long-run coefficient - Fully Modified Ordinary Least Squares Estimates (FMOLS)}

The results indicate a cointegration relationship amongst the variables therefore the FMOLS approach is employed to estimate the long run RER model and the results are presented in Table no. 4.

Table no. 4 - FMOLS long run estimation results.

Dependent variable: RER

\begin{tabular}{lc}
\hline $\begin{array}{c}\text { Explanatory } \\
\text { Variables }\end{array}$ & Coefficients \\
\hline \multirow{2}{*}{ PR } & 0.138 \\
& $(0.094)^{*}$ \\
\hline \multirow{2}{*}{ TT } & -0.667 \\
& $(0.001)^{*}$ \\
\hline \multirow{2}{*}{ NFA } & -0.001 \\
& $(0.542)$ \\
\hline R-squared & 0.921 \\
S.E. of regression & 0.201 \\
\hline
\end{tabular}

Note: probability values are in parentheses (); *10 per cent statistically significant. $* * 5$ per cent statistically significant. $* * * 1$ per cent statistically significant.

Source: Author's own computation

Table no. 4 presents the long-run coefficients results of the FMOLS estimator. The results reveal that PR is statistically significant and consistent with economic theory. TT is statistically significant and consistent with economic theory. NFA is not statistically significant and is in defiance of economic theory.

A 1 per cent increase in PR will appreciate the real exchange rate by 0.1 per cent thereby indicating a positive relationship between the two variables as stipulated by economic theory. This implies that the Balassa-Samuelson is valid and relevant to the selected African economies. In these countries, the Balassa-Samuelson theory holds. A 1 per cent increase in TT will depreciate the real exchange rate by 0.7 per cent. The relationship between terms of 
trade and the real exchange rate is negative and statistically significant. This suggest that the substitution effect dominates the income effect.

\subsection{Equilibrium real exchange rate and computed real exchange rate misalignment}

As previously explained, the permanent values of the explanatory variables in equation and Table no. 5 are derived using the Hodrick-Prescott filter. The coefficients in Table no. 5 are then imposed on the derived permanent values of the explanatory variables in order to compute the equilibrium real exchange rate. The actual and equilibrium real exchange rates are presented in Figure no. 1. The real exchange rate misalignment is presented in Figure no. 2. Figure no. 1 and no. 2 show that, there are more periods of real exchange rate undervaluation than overvaluation. Gylfason (2002) states that sustained currency overvaluation deteriorates the trade balance, speculative attacks, increased foreign debt and investment.

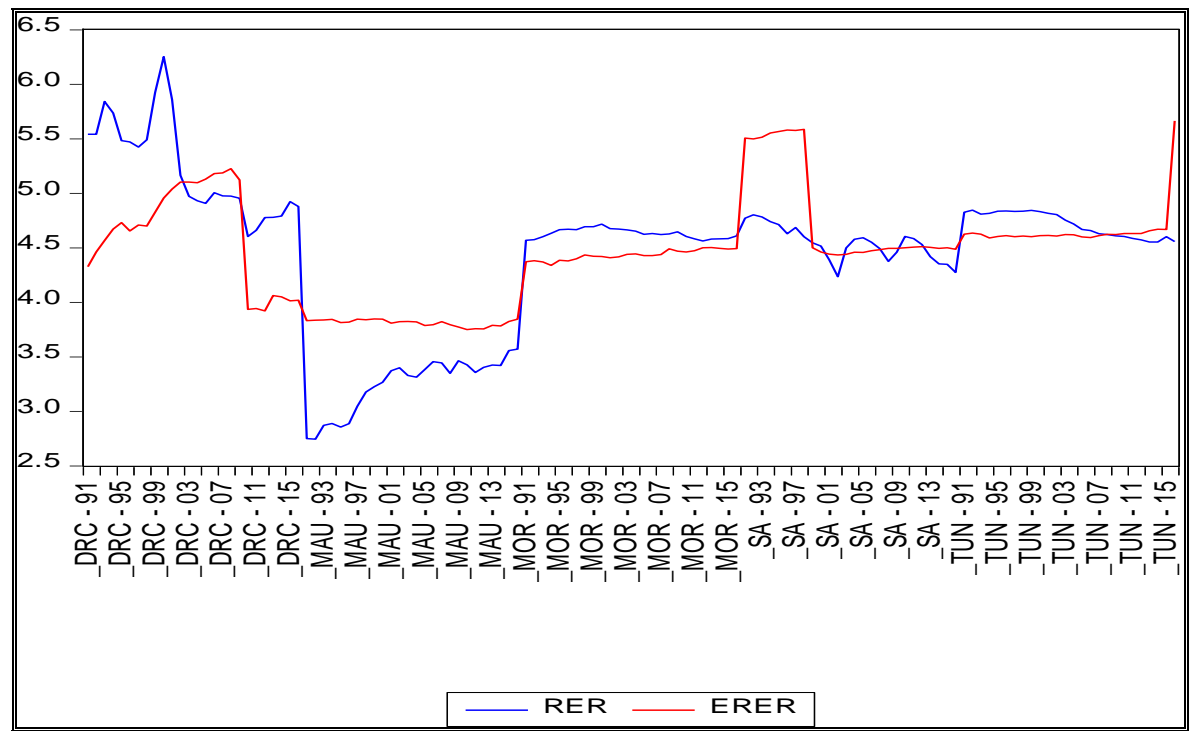

Note: DRC, MAU, MOR, SA, TUN denote Democratic Republic of Congo, Morocco, South Africa and Tunisia. ERER is the equilibrium real exchange rate and RER is the actual real exchange rate.

Source: author's own diagram

Figure no. 1 - Actual and equilibrium exchange rate 


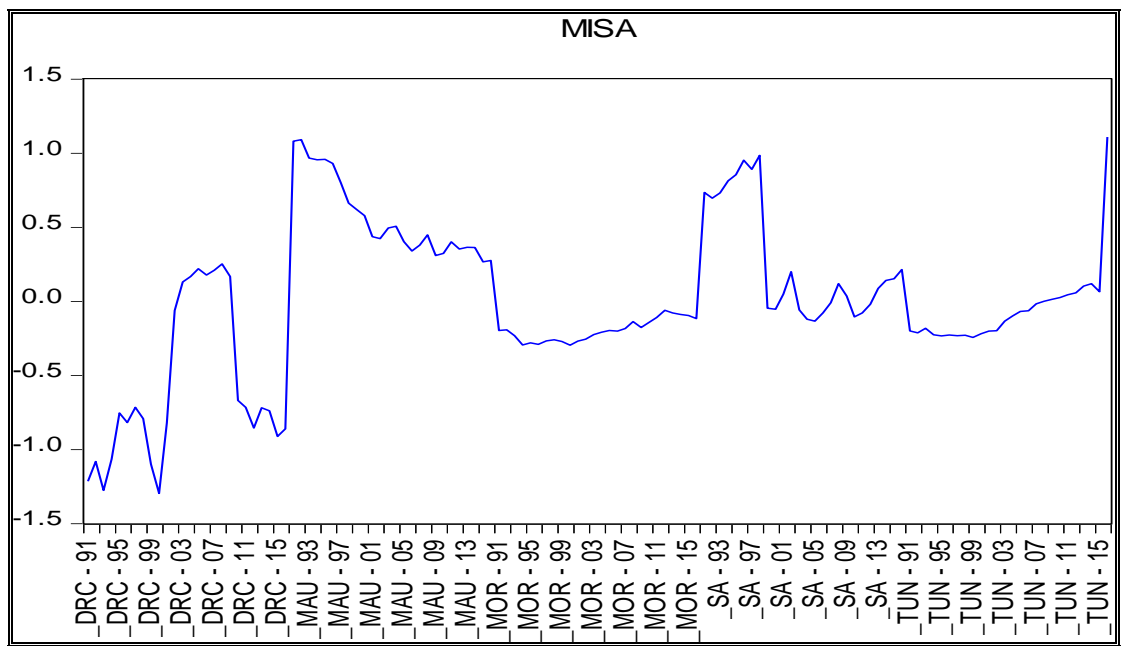

Note: DRC, MAU, MOR, SA, TUN denote Democratic Republic of Congo, Morocco, South Africa and Tunisia. MISA denotes real exchange rate misalignment.

Source: Author's own Diagram

Figure no. 2 - Real exchange rate misalignment

\subsection{The impact of real exchange rate misalignment on economic performance}

\subsubsection{Test for Stationarity}

Before estimating the impact of real exchange rate misalignment on measures of economic performance as expressed in equation (4) and (5), it is important to test for unit root of the variable. The results show that POP, INF and Y are stationary at levels while PIN, PR, ULC, FDI, X and MIS become stationary at first difference. The unit root test results are not presented here due to space limitation, but can be obtained from the authors on request. It is now appropriate to proceed with test for cointegration. Tables no. 5 and no. 6 present the stationarity test results:

Table no. 5 - Stationarity test results - Model 1

\begin{tabular}{lcccc}
\hline Variable & \multicolumn{2}{c}{ LLC Test } & \multicolumn{2}{c}{ IPS Test } \\
\hline & Levels & \multicolumn{2}{c}{ Levels } \\
\hline \multirow{2}{*}{ CY } & -3.82959 & 0.01853 & -0.34338 & Constant and Trend \\
& $(0.0001)^{*}$ & $(0.5074)$ & $(0.3657)$ & $(0.9724)$ \\
\hline \multirow{2}{*}{ LPR } & -1.15240 & -0.92410 & 1.50259 & -0.05751 \\
& $(0.1246)$ & $(0.1777)$ & $(0.9335)$ & $(0.4771)$ \\
\hline \multirow{2}{*}{ LPIN } & -1.11885 & -0.62953 & -0.02338 & -0.89388 \\
& $(0.1316)$ & $(0.2645)$ & $(0.4907)$ & $(0.1857)$ \\
\multirow{2}{*}{ LPOP } & -1.27066 & -0.46339 & -0.68724 & -1.37608 \\
& $(0.1019)$ & $(0.3215)$ & $(0.2460)$ & $(0.0844)^{*}$ \\
\multirow{2}{*}{ MIS } & -0.24806 & 0.46208 & 1.72121 & 1.22687 \\
& $(0.4020)$ & $(0.6780)$ & $(0.9574)$ & $(0.8901)$ \\
\hline
\end{tabular}




\begin{tabular}{lcccc}
\hline Variable & \multicolumn{2}{c}{ First Difference } & \multicolumn{2}{c}{ First Difference } \\
\hline \multirow{2}{*}{ LY } & Constant & Constant and Trend & Constant & Constant and Trend \\
\hline \multirow{2}{*}{ LPR } & -7.44804 & -2.18594 & -9.07668 & -3.37360 \\
& $(0.0000)^{*}$ & $(0.0144)$ & $(0.0000)^{*}$ & $(0.0004)$ \\
\hline \multirow{2}{*}{ LPIN } & -9.43767 & -7.70112 & -8.46954 & -6.76304 \\
& $(0.0000)^{*}$ & $(0.0000)^{*}$ & $(0.0000)^{*}$ & $(0.0000)^{*}$ \\
\hline \multirow{2}{*}{ LPOP } & -12.9409 & -11.0543 & -13.0238 & -11.2803 \\
& $(0.0000)^{*}$ & $(0.0000)^{*}$ & $(0.0000)^{*}$ & $(0.0000)^{*}$ \\
\hline \multirow{2}{*}{ MIS } & -2.20397 & 0.58811 & -4.61573 & -2.81867 \\
& $(0.0138)$ & $(0.7218)$ & $(0.0000)^{*}$ & $(0.0024)$ \\
\hline
\end{tabular}

Notes: p-values are in parentheses (); *indicates rejection of the null hypothesis of unit root at $10 \%$, $5 \%$ and $1 \%$ levels of significance.

Source: computed by the authors

Table no. 6 - Stationarity test results - Model 2

\begin{tabular}{|c|c|c|c|c|}
\hline \multirow[t]{3}{*}{ Variable } & \multicolumn{2}{|r|}{ LLC Test } & \multicolumn{2}{|r|}{ IPS Test } \\
\hline & \multicolumn{2}{|r|}{ Levels } & \multicolumn{2}{|r|}{ Levels } \\
\hline & Constant & Constant and Trend & Constant & Constant and Trend \\
\hline \multirow{2}{*}{ LULC } & -0.85864 & -0.05175 & -1.89422 & 0.22062 \\
\hline & $(0.1953)$ & $(0.4794)$ & $(0.0291)$ & $(0.5873)$ \\
\hline \multirow[b]{2}{*}{ LINF } & -4.78906 & -4.58762 & -4.51500 & -4.91289 \\
\hline & $(0.0000)^{*}$ & $(0.0000) *$ & $(0.0000) *$ & $(0.0000) *$ \\
\hline \multirow{2}{*}{ LFDI } & -3.85214 & -4.71136 & -4.09967 & -5.71165 \\
\hline & $(0.0001)$ & $(0.0000)$ & $(0.0000)$ & $(0.0000)$ \\
\hline \multirow{2}{*}{$\mathbf{L X}$} & -1.05856 & -1.09570 & 1.51865 & -1.55802 \\
\hline & $(0.1449)$ & $(0.1366)$ & $(0.9356)$ & $(0.0596)^{*}$ \\
\hline \multirow{2}{*}{ MIS } & -0.24806 & 0.46208 & 1.72121 & 1.22687 \\
\hline & $(0.4020)$ & $(0.6780)$ & $(0.9574)$ & $(0.8901)$ \\
\hline \multirow[t]{2}{*}{ Variable } & \multicolumn{2}{|c|}{ First Difference } & \multicolumn{2}{|c|}{ First Difference } \\
\hline & Constant & Constant and Trend & Constant & Constant and Trend \\
\hline \multirow{2}{*}{ LULC } & -7.79949 & -6.64457 & -8.18060 & -7.11526 \\
\hline & $(0.0000)^{*}$ & $(0.0000)^{*}$ & $(0.0000)^{*}$ & $(0.0000)^{*}$ \\
\hline \multirow{2}{*}{ LINF } & -14.7073 & -12.9614 & -14.1363 & -13.2194 \\
\hline & $(0.0000)^{*}$ & $(0.0000)^{*}$ & $(0.0000)^{*}$ & $(0.0000)^{*}$ \\
\hline \multirow{2}{*}{ LFDI } & -12.9409 & -11.0543 & -13.0238 & -11.2803 \\
\hline & $(0.0000)^{*}$ & $(0.0000)^{*}$ & $(0.0000)^{*}$ & $(0.0000)^{*}$ \\
\hline \multirow{2}{*}{ LX } & -8.98711 & -8.21762 & -8.11363 & -7.05212 \\
\hline & $(0.0000)^{*}$ & $(0.0000) *$ & $(0.0000)^{*}$ & $(0.0000)^{*}$ \\
\hline \multirow{2}{*}{ MIS } & -5.49298 & -4.24400 & -6.63116 & -6.34736 \\
\hline & $(0.0000)^{*}$ & $(0.0000)^{*}$ & $(0.0000)^{*}$ & $(0.0000)^{*}$ \\
\hline
\end{tabular}

Notes: p-values are in parentheses (); *indicates rejection of the null hypothesis of unit root at $10 \%$, $5 \%$ and $1 \%$ levels of significance

Source: Computed by the authors 


\subsubsection{Cointegration test results}

The results of cointegration test for both model 1 and model 2 are presented in Table no. 7. The study finds evidence of cointegration from Kao's panel cointegration tests, which rejects the null hypothesis of no cointegration.

Table no. 7 - Kao Cointegration Test Results for Models 1 and Model 2

\begin{tabular}{ccc}
\hline Model 1 & t-statistic & Probability \\
\hline ADF & -3.071 & $0.001^{*}$ \\
\hline Model 2 & t-statistic & Probability \\
\hline ADF & -2.445 & $0.007^{*}$ \\
\hline
\end{tabular}

Notes: The $\mathrm{ADF}$ is the residual-based ADF statistic. The null hypothesis is no cointegration.

* Indicates that the estimated parameters are significant at the 5 per cent level. Source: Computed by the authors

The results in Table no. 7 suggest that a panel long-run equilibrium relationship amongst the variables exists. It is now appropriate to estimate long run and short results for real exchange rate misalignment and economic growth using PMG.

\subsubsection{PMG estimation results}

This section presents the PMG estimation results for the two models using different measures of economic performance. The results for the both model 1 and 2 are presented in Tables no. 8 and no. 9 .

Table no. 8 - PMG Results - Model 1

Dependent Variable: $Y$

\begin{tabular}{lcc}
\hline Long-run Coefficients & & Probability Values \\
\hline PR & 0.370 & $(0.000)^{*}$ \\
\hline PIN & 0.723 & $(0.000)^{*}$ \\
\hline POP & -0.129 & $(0.000)^{*}$ \\
\hline MIS & -0.370 & $(0.000)^{*}$ \\
\hline Short-run Coefficients & & \\
\hline$\Delta$ PR & -0.027 & $(0.707)$ \\
\hline$\Delta$ PIN & 0.045 & $(0.585)$ \\
\hline$\Delta$ POP & -0.155 & $(0.147)$ \\
\hline DMIS & 0.048 & $(0.181)$ \\
\hline Error Correction Term & -0.018 & $(0.772)$ \\
\hline
\end{tabular}

Note * Indicates that the estimated coefficient is significant at the 10 per cent level. The numbers in brackets are probabilities

Source: Author's own Computation 
Table no. 9 - PMG Results - Model 2

Dependent Variable: ULC

\begin{tabular}{lcc}
\hline Long-run Coefficients & & Probability Values \\
\hline LINF & -0.063194 & $(0.2420)$ \\
\hline LFDI & 0.048952 & $(0.7481)$ \\
\hline LX & -0.241559 & $(0.0000)^{*}$ \\
\hline MIS & -0.111244 & $(0.4856)$ \\
\hline Short-run Coefficients & & \\
\hline$\Delta$ LINF & -0.022329 & $(0.0619)^{*}$ \\
\hline$\Delta$ LFDI & -0.030851 & $(0.1684)$ \\
\hline$\Delta \mathbf{L X}$ & 0.093189 & $(0.6290)$ \\
\hline$\Delta$ MIS & -0.158692 & $(0.1794)$ \\
\hline Error Correction Coefficient & -0.176672 & $(0.2677)$ \\
\hline
\end{tabular}

Note * Indicates that the estimated coefficient is significant at the 10 per cent level. The numbers in brackets are probabilities

Source: Author's own Computation

The results for both models show that real exchange rate has a negative impact on economic performance. However, misalignment is not statistically significant in model 2 . These results are consistent with the theoretical expectations. They suggest that maintaining the real exchange rate out of equilibrium impact negatively on economic performance.

\section{CONCLUSION}

Given the pertinence of productivity for the growth of an economy, this study investigated the Balassa-Samuelson effect on a selection of African countries aiming to attain economic growth and development. The countries under investigation were chosen on the basis of data availability. To obtain more accurate results of the hypothesis, an appropriate measure of total factor productivity was computed using the Cobb Douglas function. Additionally, real exchange rate misalignment was derived and its effects on economic performance were tested. Instead of using one measure of economic performance, the study used both the gross domestic product and unit labour costs.

The Balassa-Samuelson effect was validated for the selected African countries which are the Democratic Republic of Congo, Mauritius, Morocco, South Africa and Tunisia. The relationship between total factor productivity and the real exchange rate conformed to economic theory thereby confirming the validity of this theory. The findings are consistent with those of Iyke and Odhiambo (2017), Hussain and Haque (2020) and Tintin (2009). There were periods of undervaluation and overvaluation. The estimated models revealed an undervalued real exchange rate in the long-run test for real exchange rate misalignment. Hence, the real exchange rate was misaligned.

An undervalued real exchange rate is an ideal condition enhancing for economic growth and development in the Democratic Republic of Congo, Mauritius, Morocco, South Africa and Tunisia. Conversely, these countries need to monitor misalignment and reduce or control its impediment on economic growth and competitiveness. Furthermore, the study suggests that the Democratic Republic of Congo, Mauritius, Morocco, South Africa and Tunisia should pursue economic policies and strategies that contain real exchange rate misalignment to promote economic growth and competitiveness. Maintaining the real exchange rate out of 
equilibrium impacts negatively on economic growth. It is therefore important for countries to implement policies that maintain the real exchange rate closer to its equilibrium value. This will assist them to improve economic performance.

Though an undervaluation influences growth positively, it may prompt some inflationary pressures and the constraining of necessary resources for domestic investment which may restrict growth of supply-side potential. Policy recommendations emanating from the study include, the adoption of economic policies that will realign the real exchange rate to avoid periods of excessive undervaluation in order to propel growth. Such policies could be fiscal and monetary policies that allow monetary and financial conditions to be more accommodative and monetary policies that align the real exchange rate to its fundamentals.

\section{ORCID}

Joel Hinaunye Eita (iD http://orcid.org/0000-0002-5859-7132

Zitsile Zamantungwa Khumalo (D) http://orcid.org/0000-0002-1638-3048

Ireen Choga iD http://orcid.org/0000-0002-7911-2966

\section{References}

African Economic Outlook, 2020a. Democratic Republic of Congo Economic Outlook. from https://www.afdb.org/en/countries-central-africa-democratic-republic-congo/democratic-republiccongo-economicoutlook\#t

African Economic Outlook, 2020b. Mauritius Economic Outlook. from https://www.afdb.org/en/countries/southern-africa/mauritius/mauritius-economic-outlook

African Economic Outlook, 2020c. Morocco Economic Outlook. from https://www.afdb.org/en/countriesnorth-africa-tunisia/tunisia-economicoutlook\#:s

African Economic Outlook, 2020d. Tunisia Economic Outlook. from https://www.afdb.org/en/countriesnorth-africa-tunisia/tunisia-economicoutlook\#:s

Alex, N. B., and Simon, K. K., 2018. Macroeconomic stability in the DRC: Highlighting the role of exchange rate and economic growth. Invention Journal of Research Technology in Engineering \& Management, 2(8), 64-74.

Asea, P. K., and Mendoza, E. G., 1994. The Balassa-Samuelson model: A general-equilibrium appraisal. Review of International Economics, 2(3), 244-267. http://dx.doi.org/10.1111/j.14679396.1994.tb00043.x

Balassa, B., 1964. The Purchasing-Power Parity Doctrine: A Reappraisal. Journal of Political Economy, 72(6), 584-596.

Baltagi, B., 2008. Econometric analysis of panel data (4th ed. ed.): John Wiley \& Sons.

Barro, R. J., 1990. Government spending in a simple model of endogeneous growth. Journal of Political Economy, 98(5, Part 2), S103-S125. http://dx.doi.org/10.1086/261726

Berka, M., Devereux, M. B., and Engel, C., 2018. Real exchange rates and sectoral productivity in the Eurozone. The American Economic Review, 108(6), 1543-1581. http://dx.doi.org/10.1257/aer.20151045

Bleaney, M. F., and Tian, M., 2014. Classifying exchange rate regimes by regression methods. University of Nottingham, School of Economics Discussion Papers, 14/02.

Bordo, M. D., Choudhri, E. U., Fazio, G., and MacDonald, R., 2017. The real exchange rate in the long run: Balassa-Samuelson effects reconsidered. Journal of International Money and Finance, 75, 6992. http://dx.doi.org/10.1016/j.jimonfin.2017.03.011 
Britannica, 2021a. Democratic Republic of Congo. from https://www.britannica.com/place/DemocraticRepublic-of-the-Congo/Economy

Britannica, 2021b. Mauritius. from https://www.britannica.com/place/Mauritius

Britannica, 2021c. Morocco. from https://www.britannica.com/place/Morocco/Economys

Britannica, 2021d. South Africa. from https://www.britannica.com/place/South-Africa/Economys

Brooks, C., 2008. RATS Handbook to Accompany Introductory Econometrics for Finance: Cambridge Books. http://dx.doi.org/10.1017/CBO9780511814082

Cappuccio, N., and Lubian, D., 1992. The relationships among some estimators of the cointegrating coefficient: theory and Monte Carlo Evidence. Mimeographed. University of Padova, Padua.

Chaiboonsri, C., 2010. A panel cointegration analysis: An application to international tourism demand of Thailand. Annals of the University of Petrosani. Economics, 10(3), 69-86.

De Gregorio, J., Giovannini, A., and Wolf, H. C., 1994. International evidence on tradables and nontradables inflation. European Economic Review, 38(6), 1225-1244. http://dx.doi.org/10.1016/0014-2921(94)90070-1

Drine, I., and Rault, C., 2004. Does the Balassa-Samuelson hypothesis hold for Asian countries? An empirical analysis using panel data and cointegration tests. Applied Econometrics and International Development, 4(4), 59-84.

Eita, J. H., and Jordaan, A. C., 2013. Real exchange rate misalignment and economic performance in $\begin{array}{llll}\text { Namibia. Corporate Ownership \& Control, 10(3-4), 440-455. } & \end{array}$ http://dx.doi.org/10.22495/cocv10i3c4art3

Elbadawi, I. A., Kaltani, L., and Soto, R., 2012. Aid, real exchange rate misalignment, and economic growth in Sub-Saharan Africa. World Development, 40(4), 681-700. http://dx.doi.org/10.1016/j.worlddev.2011.09.012

Export Enterprises SA, 2021. The Economic Context of South Africa. from https://www.nordeatrade.com/fi/explore-new-market/south-africa/economical-context

Gubler, M., and Sax, C., 2019. The Balassa-Samuelson effect reversed: New evidence from OECD countries. Schweizerische Zeitschrift fur Volkswirtschaft und Statistik, 155(1), 3. http://dx.doi.org/10.1186/s41937-019-0029-3

Gylfason, T., 2002. The real exchange rate always floats. Australian Economic Papers, 41(4), 369-381. http://dx.doi.org/10.1111/1467-8454.00171

Hansen, B. E., and Phillips, P. C., 1989. 1990. Estimation and inference in models of cointegration: A simulation study. Advances in Econometrics, 8, 225-248.

Hargreaves, C. H., 1993. A review of methods of estimating cointegrating relationships. In C. H. Hargreaves (Ed.), Nonstationary Time Series Analysis and Cointegration (pp. 87-132). Oxford Oxford University Press.

Harrod, R. F., 1933. International Economics. London: Nisbet \& Cambridge University Press.

Hussain, M. E., and Haque, M., 2020. Is the Balassa-Samuelson Hypothesis still relevant? Cross-country evidence from 1950-2017. Journal of Economics and Political Economy, 7(3), 162-179.

Ishaq, M., 2016. Productivity-real exchange rate nexus: revisiting the Balassa-Samuelson hypothesis for emerging Asia. Department of Economics and Finance University of Canterbury New Zealand. https://ir.canterbury.ac.nz/handle/10092/13545.

Ito, T., and Krueger, A. O., 2007. Changes in exchange rates in rapidly developing countries: theory, practice, and policy issues (Vol. 7): University of Chicago Press.

Iyke, B. N., and Odhiambo, N. M., 2017. An empirical test of the Balassa-Samuelson hypothesis: Evidence from eight middle-income countries in Africa. Economic Systems, 41(2), 297-304. http://dx.doi.org/10.1016/j.ecosys.2016.10.001

Jobs, G., and Tunisians, G. W. T. A., 2014. The Unfinished Revolution. Development Policy Review. https://www.worldbank.org/content/dam/Worldbank/document/MNA/tunisia_report/tunisia_report _the_unfinished_revolution_eng_synthesis.pdf.

Kakkar, V., and Yan, I., 2012. Real exchange rates and productivity: Evidence from Asia. Journal of Money, Credit and Banking, 44(2-3), 301-322. http://dx.doi.org/10.1111/j.1538-4616.2011.00488.x 
Lane, M. P. R., and Milesi-Ferretti, M. G. M., 2000. External capital structure: theory and evidence. IMF Working Paper, WP/00/152. https://www.imf.org/external/pubs/ft/wp/2000/wp00152.pdf.

Lipská, E., Vlnková, M., and Macková, I., 2005. Unit labour costs. BIATEC, 13(1), 8-12.

Montiel, P. J., 2007. Equilibrium real exchange rates, misalignment and competitiveness in the Southern Cone. Macroeconomía del Desarrollo, 62. https://ideas.repec.org/p/ecr/col037/5430.html.

Moyo, T., 2016. Promoting industrialisation in Mauritius, South Africa and Botswana: Lessons for the future. Africa Development. Afrique et Developpement, 41(3), 139-163.

Obstfeld, M., Rogoff, K. S., and Rogoff, K., 1996. Foundations of international macroeconomics: MIT press.

Pedroni, P., 2001. Purchasing Power Parity Tests in Cointegrated Panels. The Review of Economics and Statistics, 83(4), 727-731. http://dx.doi.org/10.1162/003465301753237803

Pesaran, M. H., and Smith, R., 1995. Estimating long-run relationships from dynamic heterogeneous panels. Journal of Econometrics, 68(1), 79-113. http://dx.doi.org/10.1016/0304-4076(94)01644-F

Phillips, P. C., 1995. 'Fully modified least squares and vector autoregression. Econometrica, 63(5), 10231078. http://dx.doi.org/10.2307/2171721

Rabnawaz, A., and Jafar, R. S., 2015. Impact of public investment on economic growth. South Asia Journal of Multidisciplinary Studies, 1(8), 62-75. http://dx.doi.org/10.2139/ssrn.2796368

Rogoff, K., 1992. Traded goods consumption smoothing and the random walk behavior of the real exchange rate. NBER Working paper, w4119. http://dx.doi.org/10.3386/w4119

Sallenave, A., 2010. Real exchange rate misalignments and economic performance for the G20 countries. Inter Economics, 121(1), 59-80. http://dx.doi.org/10.1016/S2110-7017(13)60008-6

Samuelson, P., 1964. Theoretical notes on trade problems. Review of Economics and Statistics, 46, 145154.

Saxegaard, M., Roudet, S., and Tsangarides, C., 2007. Estimation of Equilibrium Exchange Rates in the WAEMU: A Robustness Analysis. IMF Working Paper, WP/07/194. https://ideas.repec.org/p/imf/imfwpa/07-194.html.

Sonora, R. J., and Tica, J., 2014. Harrod, Balassa, and Samuelson (re) visit Eastern Europe. Cogent Economics \& Finance, 2(1), 920557. http://dx.doi.org/10.1080/23322039.2014.920557

Tica, J., and Družić, I., 2006. The Harrod-Balassa-Samuelson Effect: A Survey of Empirical Evidence. EFZG Working Papers Series, 0607.

Tintin, C., 2009. Testing the Balassa-Samuelson hypothesis: Evidence from 10 OECD Countries. http://lup.lub.lu.se/luur/download?func=downloadFile\&recordOId=1436890\&fileOId=1646902

Tipoy, C. K., Breitenbach, M. C., and Zerihun, M. F., 2018. Exchange rate misalignment and economic growth: On the possible transmission channels for emerging economies. Cogent Economics \& Finance, 6(1), 1-18. http://dx.doi.org/10.1080/23322039.2018.1476016

Udah, E., and Ite, F., 2016. Real exchange rate misalignment and economic performance in Nigeria. Global Journal of Social Sciences, 15(1), 13-25. http://dx.doi.org/10.4314/gjss.v15i1.2

Vieira, F. V., and Macdonald, R., 2012. A panel data investigation of real exchange rate misalignment and growth. Estudos Econômicos, 42(3), 433-456. http://dx.doi.org/10.1590/S010141612012000300001

\section{Copyright}

This article is an open access article distributed under the terms and conditions of the Creative Commons Attribution-NonCommercial-NoDerivatives 4.0 International License. 